\title{
SKRINING FITOKIMIA DAN UJI AKTIVITAS ANTIOKSIDAN EKSTRAK BIJI ADAS (Foeniculum vulgare) MENGGUNAKAN METODE DPPH
}

\author{
Idza N. Sastrawan ${ }^{1)}$, Meiske Sangi ${ }^{1)}$, Vanda Kamu ${ }^{1)}$ \\ ${ }^{1)}$ Program Studi Kimia FMIPA Universitas Sam Ratulangi \\ Jl. Kampus Unnsrat, Manado 95115 \\ e-mail: dhiya_28@ymail.com; meiskesangi@gmail.com; vandakamu05@gmail.com
}

\begin{abstract}
ABSTRAK
Telah dilakukan penelitian tentang skrining fitokimia dan uji aktivitas antioksidan ekstrak biji adas. Tujuan dari penelitian ini yaitu melakukan skrining fitokimia untuk mengetahui kandungan senyawa alkaloid, triterpenoid dan steroid, flavonoid, tannin, saponin dan menetukan aktivitas antioksidan dari ekstrak biji adas. Skrining Fitokimia untuk alkaloid ditentukan dengan menggunakan pereaksi Mayer, Dregendorff, Wagner. Triterpenoid dan steroid ditentukan menggunakan $\mathrm{Mg}$ bubuk. Senyawa tannin ditentukan dengan larutan $\mathrm{FeCl}_{3} 1 \%$. Senyawa saponin ditentukan menggunakan aquades. Ekstrak biji adas diperoleh dengan metode soxhletasi menggunakan pelarut petroleum eter dan uji aktivitas antioksidan menggunakan metode 1-1-difenil-2-pikrihidrazil (DPPH). Hasil penelitian menunjukan kandungan senyawa kimia biji adas positive mengandung senyawa falvonoid, tannin dan saponin, sedangkan untuk senyawa alkaloid, triterpenoid dan steroid memberikan hasil yang negatif. Aktivitas antioksidan dengan 1000; 2000; 3000; 4000; 5000 ppm, memberikan hasil berturut-turut yaitu $48.99 \%, 33.92 \%$, $5.93 \%, 21.23 \%, 6.40 \%$. Aktivitas antioksidan biji adas tertinggi terdapat pada konsentrasi $1000 \mathrm{ppm}$ dengan hasil $48.99 \%$. Biji adas memiliki persen aktivitas antioksidan yang baik, sehingga dapat didigunakan sebagai salah satu sumber antioksidan alami.
\end{abstract}

Kata kunci : Antioksidan, Biji adas, DPPH

\section{PHYTOCHEMICAL SCREENING AND ANTIOXIDANT ACTIVITY TESTING OF FENNEL SEED EXTRACT (Foeniculum vulgare) USING THE DPPH METHOD}

\begin{abstract}
Has done research on phytochemical screening and testing fennel seed extract antioxidant activity. The purpose of this study is to determine the phytochemical screening compounds content of alkaloids, triterpenoids and steroids, flavonoids, tannins, saponins and determine the antioxidant activity of extracts of fennel seeds. Phytochemical screening for alkaloids was determined using reagent Mayer, Dregendorff, Wagner. Triterpenoids and steroids were determined using $\mathrm{Mg}$ powder. Tannin compounds determined with $1 \% \mathrm{FeCl} 3$ solution and saponin determined using distilled water. Fennel seed extract obtained by the method soxhletasi using petroleum ether solvent and antioxidant activity assay using method 1-1-diphenyl-2-pikrihidrazil (DPPH). Research has been done showing the chemical content of fennel seeds contain compounds falvonoid positive, tannins and saponins. Antioxidant activity with $1000 \mathrm{ppm}, 2000 \mathrm{ppm}$, $3000 \mathrm{ppm}, 4000 \mathrm{ppm}, 5000 \mathrm{ppm}$, respectively yield is $48.99 \%, 33.92 \%, 5.93 \%, 21.23 \%$, $6.40 \%$. The highest antioxidant activity of fennel seeds contained $1000 \mathrm{ppm}$ with $48.99 \%$ result. Fennel seeds have a good percent antioxidant activity, so it can didigunakan as a source of natural antioxidants.
\end{abstract}

Keywords : Antioxidants, Fennel seeds, DPPH

\section{PENDAHULUAN}

Di Indonesia tanaman adas telah dibudidayakan sebagai tanaman bumbu dan tanaman obat. Adas menghasilkan minyak adas, yang merupakan hasil sulingan dari serbuk buah adas yang masak dan kering, sedangkan untuk daun adas kebanyakan dimasak untuk dijadikan sayur. Minyak atsiri yang terkandung dalam biji adas 
merupakan salah satu senyawa aktif bahan dasar pembuatan obat, disamping itu minyak atsiri adas juga dapat dijadikan sebagai bahan baku industry minyak telon. Aroma wangi yang dihasilkan digunakan sebagai bahan yang memperbaiki rasa, mengharumkan ramuan obat dan makanan (Kridati, et al., 2012).

Dari pengujian yang telah dilakukan oleh Suhendra dan Arnata (2009), skrining fitokimia kadar total fenol ekstrak bubuk adas ditentukan dengan metode folin CiocalteuPhenol memberikan hasil positif dengan 2 jenis pelarut. Dimana total fenol yang diperoleh menggunakan etil asetat lebih besar dibandingkan dengan pelarut etanol. Penelitian terhadap kandungan dari minyak biji adas menurut Inneke (1995), dari kromatogram kromatografi gas (GC) telah diidentifikasi 14 macam komponen penyusun minyak biji adas, yaitu golongan monoterpen, phenol, dan golongan keton. Yang termasuk golongan phenol adalah anetol dan iso anetol 58.52\%; golongan monoterpen terdiri dari $\alpha$-pinen $3 \%$, camphene $\quad 0.33 \%, \quad \alpha$-limonene $\quad 3.5 \%$; sedangkan golongan keton adalah dcamphore $0.39 \%$, fenchone $26.7 \%$.

Komponen kimia yang berperan sebagai antioksidan adalah senyawa fenolik dan polifenolik. Senyawa-senyawa golongan tersebut banyak terdapat di alam, terutama pada buah-buahan dan rempah yang memiliki kemampuan menangkap radikal bebas. Salah satu metode yang digunakan dalam menguji aktivitas antioksidan yaitu metode DPPH (1,1-difenil-2-pikrilhidrazil). Metode pengujian ini merupakan metode yang konvensial dan telah lama digunakan untuk penetapan aktivitas senyawa antioksidan. Menurut Widyastuti (2010), metode DPPH mudah digunakan, cepat, cukup teliti dan baik digunakan dalam pelarut organik.

Reaksi oksidasi terjadi setiap saat, ketika manusia bernapas terjadi reaksi oksidasi. Reaksi ini mencetuskan terbentuknya radikal bebas yang sangat aktif, yang dapat merusak struktur serta fungsi sel. Namun, reaktivitas radikal bebas itu dapat dihambat oleh sistem antioksidan yang melengkapi sistem kekebalan tubuh (Winarsi, 2007).

Radiasi ionisasi merupakan salah satu penyebab terbentuknya radikal bebas, baik secara langsung atau akibat cedera sel dan peradangan. Radikal bebas adalah suatu atom atau molekul yang sangat reaktif dengan elektron yang tidak memiliki pasangan. Radikal bebas mencari reaksireaksi agar dapat memperoleh kembali elektron pasangannya. Selain itu, radikal bebas dapat mengalami tubrukan kaya energi dengan molekul lain, yamg merusak ikatan didalam molekul, sehingga radikal bebas dapat merusak membran sel atau DNA sel yang rentan (Corwin, 2009).

Berdasarkan uraian di atas, maka dianggap perlu untuk melakukan skrining fitokimia untuk mengetahui kandungan senyawa alkaloid, triterpenoid/steroid, flavonoid, tannin, dan saponin dalam ekstrak biji adas dan pengujian aktivitas antioksidan dari ekstrak biji adas.

\section{METODOLOGI PENELITIAN}

\section{Waktu dan Tempat Penelitian}

Penelitian ini dilaksanakan selama 1 bulan (Agustus - September 2013 di Laboratorium Kimia Jurusan Kimia FMIPA UNSRAT Manado.

\section{Alat dan Bahan}

Alat-alat yang digunakan adalah alat soxhlet, evaporator, timbangan digital, pipet mikro, desikator, oven, spektrofotometer UV-Vis, ayakan, kertas saring, alat-alat gelas lainnya.

Bahan-bahan yang digunakan dalam penelitian ini adalah biji adas, pelarut petrolium eter, etanol, aquades, magnesium bubuk, asam klorida, besi(III)klorida $1 \%$, DPPH (1-1-difenil-2-pikrihidrazil).

\section{Prosedur Penelitian}

\section{Preparasi Sampel}

Sampel dari penelitian ini adalah biji tanaman adas yang diperoleh dari pasar bersehati kota Manado. Biji adas dalam keadaan kering, dibersihkan dan dibuat serbuk.

\section{Ekstraksi}

Serbuk biji adas diekstraksi dengan menggunakan metode soxhletasi. Mula-mula $50 \mathrm{~g}$ serbuk biji adas dimasukan ke dalam alat soxhletasi yang telah dibungkus dengan kertas saring. Ekstraksi menggunakan pelarut petroleum eter $500 \mathrm{~mL}$ sampai pelarut berwarna bening dengan waktu 4-5 jam. Filtrat dikumpulkan lalu diuapkan 
dengan evaporator hingga diperoleh ekstrak kental.

\section{Penentuan Kadar Air (Sudarmadji, 1989)}

Kadar air ditentukan dengan menimbang $3 \mathrm{~g}$ sampel. Sampel dimasukan ke dalam oven pada suhu $105^{\circ} \mathrm{C}$ selama 3-5 jam, kemudian dikeluarkan dari oven dan didinginkan dalam desikator selama 30 menit, setelah itu sampel ditimbang. Perlakuan ini dilakukan beberapa kali hingga berat sampel konstan. Kadar air dihitung berdasar rumus:

$\%$ Kadar air $=\frac{\text { berat awal }- \text { berat } \text { akhir }}{\text { berat awal }} \times 100 \%$

4. Skrining Fitokimia (Sangi, et al., 2008)

\section{Senyawa flavonoid :}

Sebanyak $200 \mathrm{mg}$ sampel biji adas yang telah diekstrak dengan $5 \mathrm{ml}$ etanol dan dipanaskan selama lima menit di dalam tabung reaksi. Selanjutnya ditambahkan $\mathrm{HCl}$ pekat, kemudian ditambahkan $0.2 \mathrm{~g}$ bubuk Mg, hasil positif ditunjukkan dengan timbulnya warna merah tua (magenta) dalam waktu 3 menit.

\section{Senyawa saponin :}

Sebanyak 2 g sampel biji adas yang telah dihaluskan dimasukan ke dalam tabung reaksi, ditambahkan air suling sehingga seluruh cuplikan terendam, dididihkan selama 2-3 menit, dan selanjutnya didinginkan, kemudian dikocok kuat-kuat. Hasil positif ditunjukan dengan terbentuk buih putih yang stabil.

\section{Senyawa tannin :}

Sebanyak $20 \mathrm{mg}$ sampel biji adas yang telah dihaluskan, ditambah etanol sampai sampel terendam semuanya. Kemudian sebanyak $1 \mathrm{ml}$ larutan dipindahkan ke dalam tabung reaksi dan ditambahkan 2-3 tetes larutan $\mathrm{FeCl}_{3} 1 \%$. Hasil positif ditunjukan dengan terbentuknya warna hitam kebiruan atau hijau.

\section{Uji Aktivitas Antioksidan dengan Metode DPPH}

Uji aktivitas antioksidan dari ekstrak biji adas diukur dengan metode Gaulejac et al. dalam Kiay et al. (2011). Sebanyak 0.005 ; 0.01; 0.015; 0.02; dan 0.025 g ekstrak biji adas metode ekstraksi soxhletasi ditambahkan $5 \mathrm{~mL}$ etanol untuk hasil konsentrasi 1000, 2000, 3000, 4000, 5000 ppm, ditambahkan masing-masing dengan $\quad 1.5 \mathrm{~mL}$ larutan 1,1-difenil-2pikrilhidrazil (DPPH) dan divortex selama 2 menit. Tingkat berkurangnya warna dari larutan menunjukkan efisiensi penangkap radikal. Absorbansi dibaca dengan spektrofotometer pada $\lambda 517 \mathrm{~nm}$ setelah diinkubasi selama 30 menit. Aktivitas penangkap radikal bebas dihitung sebagai persentasi berkurangnya warna DPPH dengan menggunakan persamaan:

Aktivitas penangkap radikal bebas (\%)

$$
=1-\frac{\text { absorbansi sampel }}{\text { absorbansi kontrol }} \times 100 \%
$$

\section{HASIL DAN PEMBAHASAN}

\section{Penentuan Kadar Air}

Penentuan kadar air merupakan pengukuran banyaknya air yang masih terdapat dalam sampel biji adas. Penentuan kadar air dilakukan sebelum proses ekstraksi. Hasil penelitian menunjukan bahwa kadar air dalam sampel biji adas $14.09 \%$. Kadar air dalam bahan akan mempengaruhi ketahanan dalam penyimpanan dan aktivitas dari mikroba. Sehingga kadar air yang rendah akan membuat penyimpanan bahan lebih lama.

\section{Skrining Fitokimia}

Hasil skrining fitokimia biji adas dapat dilihat pada Tabel 1.

Tabel 1. Hasil skrining fitokimia biji adas

\begin{tabular}{|c|c|c|}
\hline $\begin{array}{c}\text { Golongan } \\
\text { Senyawa }\end{array}$ & Hasil uji & Keterangan \\
\hline $\begin{array}{c}\text { Alkaloid : } \\
\text { Mayer } \\
\begin{array}{c}\text { Dragendorff } \\
\text { Wagner }\end{array}\end{array}$ & - & $\begin{array}{c}\text { Tidak terbentuk } \\
\text { endapan }\end{array}$ \\
\hline $\begin{array}{c}\text { Triterpenoid / } \\
\text { steroid }\end{array}$ & - & $\begin{array}{c}\text { Tidak terjadi } \\
\text { perubahan } \\
\text { warna }\end{array}$ \\
\hline Flavonoid & + & Merah tua \\
\hline Tannin & + & Biru kehitaman \\
\hline Saponin & + & Buih \\
\hline
\end{tabular}

Berdasarkan hasil skrining fitokimia biji adas yang terdapat pada Tabel 1, menunjukan bahwa biji adas mengandung flavonoid, tannin dan saponin. Ini membuktikan biji adas mengandung senyawa aktif metabolit sekunder. Pada pengujian flavonoid menunjukan hasil positif dengan perubahan warna merah tua, untuk uji tannin hasil positif ditunjukan dengan perubahan warna biru kehitaman dan 
untuk uji saponin hasil positif ditunjukan dengan adanya busa yang terbentuk. Untuk uji alkaloid, triterpenoid dan steroid memberikan hasil negatif karena tidak adanya endapan maupun perubahan warna yang terjadi pada saat penambahan pereaksi. Kandungan flavonoid dan tannin yang terkandung didalam biji menunjukan bahwa, biji adas berpotensi sebagai antioksidan.

Senyawa kimia yang bermanfaat dari tumbuhan adalah hasil dari metabolit sekunder yang berupa alkaloid, steroida/terpenoida, flavonoid atau fenolik. Senyawa ini diantaranya berfungsi sebagai pelindung terhadap serangan atau gangguan yang ada disekitar, sebagai antibiotik dan juga sebagai antioksidan (Atmoko dan Ma'ruf, 2009).

\section{Uji Aktivitas Antioksidan}

Hasil uji aktivitas antioksidan ekstrak biji adas metode soxhletasi dengan senyawa 1,1 difenil-2-pikrihidrazil atau DPPH dapat dilihat pada Gambar 1 berikut :

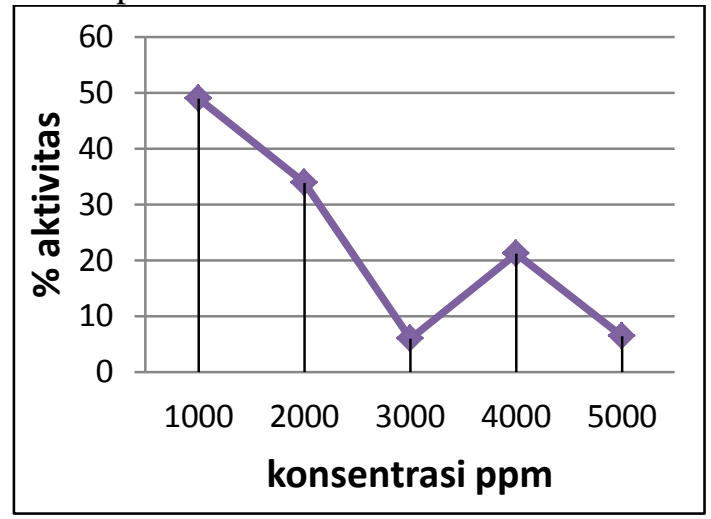

Gambar 1. Hasil uji aktivitas antioksidan ekstrak biji adas metode ekstraksi soxhletasi.

Kemampuan penangkapan radikal DPPH oleh suatu antioksidan dinyatakan dengan nilai persen penangkapan radikal. Nilai yang semakin tinggi menunjukkan bahwa sampel senyawa yang digunakan memang berpotensi sebagai antioksidan (Ridwina, 2008). Berdasarkan penelitian yang telah dilakukan, penambahan larutan DPPH pada sampel ditandai dengan berubahnya warna ungu menjadi warna kuning yang berarti adanya proses penangkapan radikal bebas. Gambar 1 menunjukkan aktivitas antioksidan tertinggi yaitu pada konsentrasi 1000 ppm sebesar $48.99 \%$, sedangkan untuk konsentrasi yang lebih tinggi aktivitas antioksidannya berkurang atau tidak ada aktivitas. Dari hasil yang telah diperoleh, biji adas memiliki potensi aktivitas antioksidan walaupun aktivitasnya kurang dari $50 \%$. Untuk konsentrasi yang lebih tinggi yaitu 2000, 3000, 4000 dan 5000 ppm, diharapkan memberikan aktivitas yang tinggi tetapi sebaliknya semakin tinggi, semakin berkurangnya aktivitas atau tidak adanya aktivitas. Ini kemungkinan disebabkan kandungan minyak atsiri yang tinggi, sedangkan untuk konsentrasi 3000 ppm kurva yang menurun kemungkinan diakibatkan karena tidak homogennya pengambilan ekstrak pada saat penimbangan pembuatan konsentrasi larutan. Menurut Prakosa, et al., (2013), biji adas memiliki kandungan minyak atsiri yang tinggi dengan penyusun utama yaitu anetol $60 \%$. Salah satu khasiat anetol adalah sebagai karminatif. Sebelumnya telah dilakukan penelitian oleh Suhendra dan Arnata (2009), hasil aktivitas antioksidan dengan konsentrasi $1000 \quad \mathrm{ppm}$ kebawah, memberikan hasil yang optimal pada konsentrasi 975 ppm. Ini membuktikan bahwa hasil pengujian aktivitas antioksidan tertinggi ada pada sekitaran $1000 \mathrm{ppm}$.

DPPH yang merupakan suatu molekul radikal bebas dengan warna ungu dapat berubah menjadi senyawa yang stabil dengan warna kuning oleh reaksi dengan antioksidan, dimana antioksidan memberikan satu elektronnya pada DPPH sehingga terjadi peredaman pada radikal bebas DPPH. Elektron yang tidak berpasangan pada DPPH memberikan suatu absorbansi yang kuat, maksimum pada $\lambda=517 \mathrm{~nm}$ dan berwarna ungu. Peredaman radikal bebas oleh antioksidan terjadi ketika electron tidak berpasangan menjadi berpasangan dengan adanya donor hidrogen, sehingga membentuk DPPH yang stabil (Yuhernita dan Juniarti, 2011).

Struktur DPPH dan reaksinya dengan antioksidan ditunjukan pada Gambar 2. 


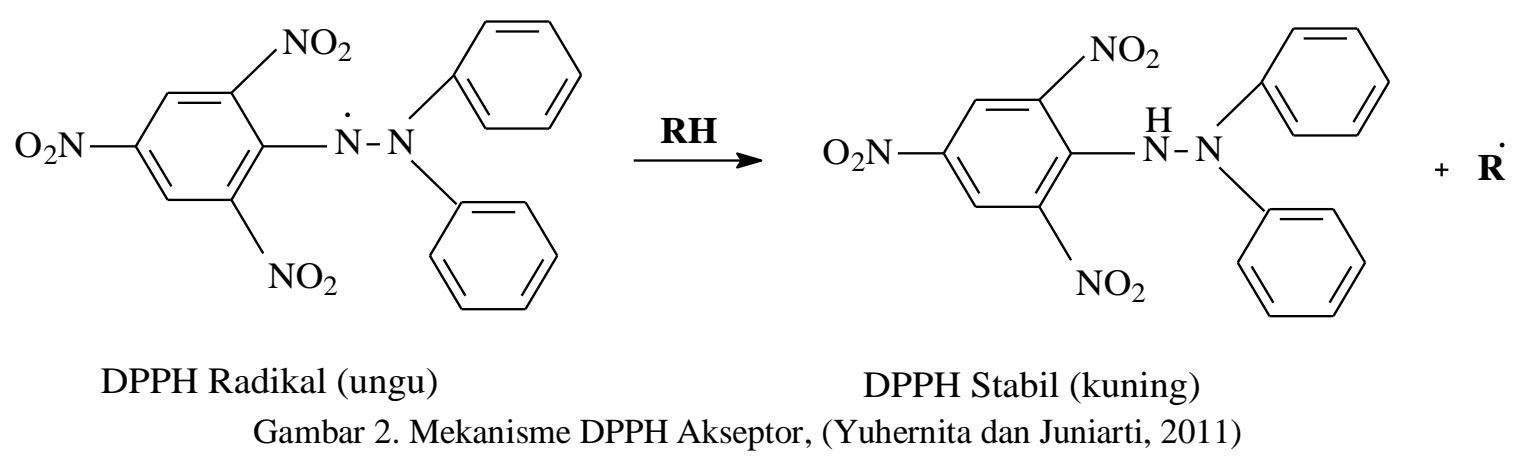

\section{KESIMPULAN}

1. Hasil skrining fitokimia, biji adas mengandung senyawa aktif flavonoid, tannin dan saponin.

2. Ekstrak biji adas mengandung aktivitas antioksidan dengan aktivitas tertinggi pada 1000 ppm yaitu $48.99 \%$. Uji aktivitas antioksidan biji adas metode DPPH menunjukkan aktivitas yang baik.

\section{DAFTAR PUSTAKA}

Atmoko, T. dan A. Ma'ruf. 2009. Uji Toksisitas dan Skrining Fitokimia Ekstrak Tumbuhan Sumber Pakan Orangutan Terhadap Larva Artemia Salina L. Jurnal Penelitian dan Konservasi Alam. 6(1): 37-45.

Corwin, E.J. 2009. Buku saku Patofisiologi. Edisi ketiga. Penerjemah: Yudha, E.K., Wahyuningsi, E., Yulianti, D., dan Karyuni, P.E. Jakarta: Penerbit Buku Kedokteran EGC.

Inneke. 1995. Karakterisasi Sifat Fisiko Kimia dan Analisa Profil Deskriptif Flavor Minyak Biji adas (Foeniculum Vulgare Mill) [Skripsi]. Fakultas Teknologi Pertanian IPB, Bogor.

Kiay, N., E. Suryanto dan L. Mamahit. 2011. Efek Lama Perendaman Ekstrak Kalamansi (Citrus microcarpa) terhadap Aktivitas Antioksidan Tepung Pisang Goroho (Musa spp.). Chemistry Progress. 4: 27-33.

Kridati, E. M., E. Prihastanti dan S. Haryanti. 2012. Rendemen Minyak Atsiri dan Diameter Serta Ukuran Sel Minyak Tanaman Adas (Foeniculum vulgare Mill) yang Dibudidayakan di
Kabupaten Semarang dan Kota Salatiga. Buletin Anatomi dan Fisiologi. 20(1): 1-17.

Prakosa, A.H., I. D. Pamungkas, dan D. Ikhsan. 2013. Pengaruh Waktu Pada Penyulingan Minyak Adas (Fennel Oil) Dari Biji dan Daun Adas Dengan Metode Uap dan Air. Jurnal Teknologi Kimia dan Industri. 2(2): 14-17.

Ridwana, G. 2008. Perbandingan Pengukuran Aktivitas Antioksidan Dari Ekstrak Etanol Minyak Atsiri Lempuyang Gajah [Skripsi]. FMIPA $\mathrm{IPB}$, Bogor.

Sangi, M., M. R. J. Runtuwene., H. E. I. Simbala dan V. M. A. Makang. 2008. Analisa Fitokimia Tumbuhan Obat Di Minahasa Utara. Chem. Prog. 1(1): 47-53.

Sudarmadji, S. 1989. Analisa Bahan Makanan dan Pertanian. Liberti. Yogyakarta.

Suhendra, L., dan I. W. Arnata. 2009. Potensi Aktivitas Antioksidan Biji Adas Sebagai Penangkap Radikal Bebas. Jurnal Agrotekno. 15(2): 66-71.

Widyastuti, N. 2010. Pengukuran Aktivitas Antioksidan Dengan Metode CUPRAC, DPPH dan FRAP Serta Kolerasinya Dengan Fenol dan Flavonoid Pada Enam Tanaman [Skripsi]. FMIPA Institut Pertanian Bogor, Bogor.

Winarsi, H. 2007. Antioksidan Alami dan Radikal Bebas. Cetakan kelima. 
Yogyakarta: Penerbit Kanisus (Anggota IKAPI).

Yuhernita dan Juniarti. 2011. Analisa

Senyawa Metabolit Sekunder dari
Ekstrak Metanol Daun Surian yang Berpotensi sebagai Antioksidan. Makara, Sains. 15(1): 48-52. 